\title{
Effect of Different Modes of Pollination on Yield and Quality Paramaters of Pumpkin, Cucurbita moschata (Duch. ex Lam) Fruits
}

\author{
Lalita*, Yogesh Kumar and Vikas \\ COA, Department of entomology, CCS Haryana Agricultural University, Hisar 12500, India \\ *Corresponding author
}

\section{A B S T R A C T}

The maximum number of fruits set was recorded in open-pollination + hand-pollination treatment $(80.42 \%$ and $77.14 \%)$ and open-pollination (78.85\% and $75.00 \%)$, followed by

\begin{tabular}{|l|}
\hline Ke y w or d s \\
$\begin{array}{l}\text { Pumpkin, fruit set, } \\
\text { fruit weight, open } \\
\text { pollination and } \\
\text { hand pollination }\end{array}$ \\
\hline Article Info \\
\hline $\begin{array}{l}\text { Accepted: } \\
\text { 25 May } 2018 \\
\text { Available Online: } \\
\text { 10 June } 2018\end{array}$ \\
\hline \hline
\end{tabular}
hand-pollination $(65.42 \%$ and $61.42 \%)$ in C-1076 and C-1106 cultivar respectively. Without insect pollination treatment resulted in zero per cent fruit set in both the pumpkin cultivars (C-1076 and C-1106). Mean fruit weight, fruit length, fruit diameter, number of seeds per fruit, seed test weight, seed germination percentage, seed vigour I and seed vigour II was maximum open-pollination + hand-pollination $(2725.70 \mathrm{~g}, 37.05 \mathrm{~cm}, 43.08$ $\mathrm{cm}, 457,88.88 \mathrm{~g}, 90.75$ per cent, 3058.93 and 5.24, respectively) followed by openpollination and hand-pollination in pumpkin (C-1076). Likewise in C-1106, maximum fruit set was recorded in open-pollination + hand-pollination treatment $(77.14 \%)$ and openpollination $(75.00 \%)$, followed by hand-pollination $(61.42 \%)$. Similarly, Mean fruit weight, fruit length, fruit diameter, number of seeds per fruit, seed test weight, seed germination percentage, seed vigour I and seed vigour II was maximum (2131.20 g, 27.87 $\mathrm{cm}, 48.32 \mathrm{~cm}, 407,85.91 \mathrm{~g}, 82.75$ per cent, 3006.98 and 5.18, respectively) in openpollination + hand-pollination followed by open-pollination and hand-pollination in C1106 cultivars. Hence in both cultivars of pumpkin, open-pollination + hand-pollination were the best treatment followed by open pollination and hand pollination.

\section{Introduction}

Pumpkins are grown all around the world for a variety of reasons ranging from agricultural purposes to ornamental and commercial sales and recreational purposes. Most parts of the pumpkin are edible; including the fleshy shell, seeds, leaves and even the flowers, when ripe, pumpkin can be boiled, baked, steamed or roasted. In South Asian countries such as India, pumpkin in addition is cooked with butter, sugar and spices in a dish called "Kaddu Ka Halwa". Pollination by honey bees play an important role in setting of fruit.
Without insect pollinated flower produced no fruit set.

Cervancia and Bergonia (1991) ${ }^{[1]}$ found that per cent fruit set of bee-pollianted and open pollinated (uncaged) plants did not differ significantly in Phillipines but was about twice that of non-pollinated plant. They further observed that fruits were heavier $(0.87 \mathrm{~kg})$ and more uniform than those of open pollinated plants $(0.6 \mathrm{~kg})$, while fruits from nonpollinated plants were the shortest and the lightest $(0.36 \mathrm{~kg})$. 


\section{Materials and Methods}

The studies were carried out at the Research farm and Apiculture Laboratory of the Department of Entomology and Laboratory of Department of Seed Science and Technology, Chaudhary Charan Singh Haryana Agricultural University, Hisar during June to December, 2013 on two cultivars of pumpkin viz., C-1076 and C-1106.

Flowering began during Aug-Sept, 2013. For study the effect of different mode of pollination on fruit set, yield and quality parameters of $C$. moschata cultivars, the following four treatments were taken:

Without insect pollination (WIP)

Open pollination $(\mathrm{OP})$

Hand pollination (HP)

Hand pollination + Open pollination (HP $+\mathrm{OP})$

Ten female flower buds about to open were enclosed with butter paper bags to exclude the insect pollinators (WIP). Likewise, ten female flower buds were tagged for open pollination (OP).

Similarly ten female flower buds enclosed in butter paper bags were pollinated by hand (HP) after opening and enclosed again. In another set, ten female flowers were pollinated by hand and were left without bags for open pollination $(\mathrm{HP}+\mathrm{OP})$.

Pin holes were made in the butter paper bags so that the environment inside the bags could not change. The butter paper bags were fixed on the flowers by tying thread. Observations were made on the fruit set (\%), fruit size (length and diameter in $\mathrm{cm}$ ), fruit weight $(\mathrm{g}$ ), number of seeds set per fruit, seed germination per cent and seed vigour. Fruit were picked for observations after $28^{\text {th }}$ day of their setting.

\section{Per cent fruit set (\%)}

Per cent fruit set was calculated by the formula as given below:

Total number of fruit set

Per cent fruit set $=\longrightarrow \times 100$

Total number of flowers tagged

\section{Fruit weight (g)}

In each treatment, weight of the individual fruit was taken with a single pan electronic balance one by one and then averaged.

\section{Fruit length (cm)}

In each treatment, fruit length in centimeters was recorded by measuring the distance from one end to other end of the fruit, with the help of a measuring tape.

\section{Fruit diameter}

The girth of the fruit was measured in centimeter with the help of a measuring tape from three places and then averaged.

\section{Number of seeds per fruit}

Number of seeds per fruit was counted manually with hands after picking of the fruit.

\section{Test weight (g)}

Weight of the 1000 seeds was taken on an electronic balance and taken as test weight. Three replications in each treatment were taken.

Germination percentage, seed vigour I and seed vigour II

To record the germination percentage of the 
seeds, 100 seeds of each treatment were placed on sufficiently moistened rolled germinating papers (Between the papers) at $20^{\circ} \mathrm{C}$ in the seed germinator. The data on shoot length, root length and dry weight of the seedling were recorded on 10 seedlings randomly selected from 8 days old seedlings. After recording the data on shoot and root length in $\mathrm{cm}$, the seedlings were kept in the oven at $85^{\circ} \mathrm{C}$ till their dry weight stabilized. The data was expressed as dry weight (g) per seedling. The whole set of experiment was repeated with three replications.

Seed vigour $\mathrm{I}=$ Germination $(\%) \mathrm{x}$ seedling length $(\mathrm{cm})$

Sees vigour $\mathrm{II}=$ germination $(\%) \mathrm{x}$ seedling dry weight (g)

\section{Statistical analysis}

Completely randomized design (CRD) Data was statistically analyzed by OPSTAT system software of the CCSHAU, Hisar and significant or non-significant difference was examined with the help of critical difference (CD) at 5\% level of significance was worked out.

\section{Results and Discussion}

Effect of different modes of pollination on fruit set percentage in two pumpkin cultivars

The perusal of data presented in table 1 . Reveal that the mean per cent fruit set in different modes of pollination differed significantly. In both the cultivars, (C-1076 and $\mathrm{C}$-1106) the treatment open-pollination+ hand-pollination and open-pollination produced significantly greater number of fruit set $(80.42,77.14$ and 78.85, 75.00) respectively followed by hand-pollination $(65.42,61.42)$. The least or zero per cent fruit set was observed in without insect pollination
(WIP) treatment (in which the flowers were excluded from the insect pollination by covering flower with butter paper bag).

Effect of different modes of pollination on fruit weight, fruit length and fruit diameter in two cultivars of pumpkin

The data depicted that the mean fruit weight (g) was recorded 1553.60 (range 525-2244) in C-1076 and 1016.65 (range 798-1216) in C1106 cultivar in hand-pollinated plants. It was 2322.60 (range 1982-2610) in C-1076 and 1383.92 (range 1250-1550) in C-1106 cultivar in open-pollinated plants. Similarly, the mean fruit weight $(\mathrm{g})$ in open-pollination + handpollination treatment in $\mathrm{C}-1076$ cultivar was 2725.70 (range 2119-2940) and in C-1106 cultivar was 2131.20 (range 1558-2900). Irrespective of different modes of pollination, the fruit weight of C-1076 cultivar was significantly higher than the fruit weight of C1106 cultivar. Data on the effect of different modes of pollination on fruit length in two pumpkin cultivar differed significantly. The mean fruit length $(\mathrm{cm})$ was 27.15 (range 16.00-34.25) in C-1076 and 21.25 (range 18.75-25.00) in C-1106 cultivar in handpollinated plants. In open-pollination treatment, the average fruit length was 33.05 (range 27.50 - 38.50) in C-1076 and 24.25 (range $22.50-25.00)$ in C-1106 cultivar. It was 37.05 (range 31.25-40.75) in C-1076 and 27.87 (range 23.75-37.00) in C-1106 cultivar under open-pollination + hand-pollination treatment. Data in respect to the effect of different modes of pollination on fruit diameter in two pumpkin cultivars, exhibit that the average fruit diameter $(\mathrm{cm})$ in two pumpkin cultivars was the highest in openpollination + hand-pollination (43.08 and $48.32 \mathrm{~cm}$, respectively) which was higher than fruit diameter recorded in from handpollination (37.35 and 38.57) and openpollination (41.53 and 45.53) treatments. Irrespective of different modes of pollination, the average fruit diameter of $\mathrm{C}-1106$ cultivar 
was significantly higher than fruit diameter of C-1076 cultivar. Without insect pollination treatment resulted in zero per cent fruit set in both the cultivars in all treatments. Therefore, no yield and quality parameters could be recorded. Present results are in conformity with the observations of Deyto and Cervancia $(2009)^{[2]}$ on pumpkin in Philippines and of Grewal and Sidhu (1979) ${ }^{[3]}$ on cucurbits yield in India. In Pakistan, Sarwar et al., (2008) ${ }^{[4]}$ reported that the highest per cent fruit set in cucumber was observed in open-pollinated plants with bees $(85.40 \%)$, followed by plants caged with bees $(81.28 \%)$ and the lowest per cent fruit set was recorded in plants caged without bees $(16.4 \%)$.

Effect of different modes of pollination on number of seed per fruit, seed test weight (g) and seed germination (\%) in two pumpkin cultivars

Data in respect to the effect of different modes of pollination on number of seeds per fruit in two pumpkin cultivars are presented in Table 3 . It is clear from the data that the average number of seeds per fruit in two pumpkin cultivars, (C-1076 and C-1106) was the highest in open-pollination + hand-pollination (457 and 407 respectively) which was significantly higher than the treatment from hand-pollination (237 and 219) and openpollination (290 and 293) treatment. Irrespective of different modes of pollination, the average number of seeds per fruits of pumpkin in two cultivars differed significantly.

Data regarding the effect of modes of pollination on seed test weight in two pumpkin cultivars are given in Table 6. The average seed test weight (g) was maximum (88.88 and 85.91) under open-pollination + hand-pollination treatment in C-1076 and C1106 cultivar respectively, which was significantly higher than the seed test weight under open-pollination (84.31 and 64.18) and hand-pollination (82.75 and 59.14) in both cultivars. Irrespective of different modes of pollination, the seed test weight of C-1076 cultivar was maximum in all treatments which were significantly higher than the seed test weight of C-1106 cultivar. The average seed germination per cent was maximum (90.75 and 82.75) under open-pollination + handpollination treatment in C-1076 and C-1106, cultivar respectively, which was significantly higher than the seed germination per cent under open-pollination $(90.00,80.60)$ and hand-pollination (84.65 and 75.00) in both cultivars. Irrespective of different modes of pollination, the seed germination percentage of C-1076 cultivar was maximum in all treatments which were significantly higher than the seed germination percentage of C1106 cultivar.

In all the treatment related to different parameters, i.e. no. of seed, seed test weigh and seed germination percent, there was no fruit recorded in the without insect pollination treatment. Nogueira-Couto and Calmona (1993) [5] studied the insect pollination of cucumber with three different treatments, i.e., areas netted without honey bees, netted with honey bees and open-pollinated. Plots netted with bees yielded more number of fruits $/ \mathrm{m}^{2}$ and heavier and higher quality fruits than other plots. Jayaramappa et al., $(2011)^{[6]}$ noted that the number of fruits per plot was higher in Luffa acutangula crop sprayed with bee attractant when compared to the untreated crop thus ascertaining the role of bee in increase the fruit set. The mean fruit weight was observed maximum (2725.70 and 2131.20 g) under open-pollination + hand-pollination, which was significantly higher than the mean fruit weight under open-pollination (2322.60 and $1383.92 \mathrm{~g}$ ) and hand-pollination (1553.60 and $1016.65 \mathrm{~g}$ ) in both cultivars i.e C-1076 and $\mathrm{C}-1106$ respectively. 
Table.2 Effect of different modes of pollination on fruit weight, fruit length and fruit diameter in two pumpkin cultivars

\begin{tabular}{|c|c|c|c|c|c|c|c|c|c|c|c|c|}
\hline \multirow[t]{3}{*}{ Mode of pollination } & \multicolumn{4}{|c|}{ Fruit weight (g) in two cultivars } & \multicolumn{4}{|c|}{ Fruit length (cm) } & \multicolumn{4}{|c|}{ Fruit Diameter (cm) } \\
\hline & \multicolumn{2}{|c|}{ C-1076 } & \multicolumn{2}{|c|}{ C-1106 } & \multicolumn{2}{|c|}{ C-1076 } & \multicolumn{2}{|c|}{ C-1106 } & \multicolumn{2}{|c|}{ C-1076 } & \multicolumn{2}{|c|}{ C-1106 } \\
\hline & Mean & Range & Mean & Range & Mean & Range & Mean & Range & Mean & Range & Mean & Range \\
\hline Hand pollination & 1553.60 & $525-2244$ & 1016.65 & $\begin{array}{l}798- \\
1216\end{array}$ & 27.15 & $\begin{array}{l}16.00- \\
34.25\end{array}$ & 21.25 & $\begin{array}{l}18.75- \\
25.00\end{array}$ & 37.35 & $\begin{array}{l}23.65- \\
42.90\end{array}$ & 38.57 & $31.25-44.57$ \\
\hline Open pollination & 2322.60 & $\begin{array}{l}1982- \\
2610\end{array}$ & 1383.92 & $\begin{array}{l}1250- \\
1550\end{array}$ & 33.05 & $\begin{array}{l}27.50- \\
38.50\end{array}$ & 24.25 & $\begin{array}{l}22.50- \\
25.00\end{array}$ & 41.53 & $\begin{array}{l}36.32- \\
45-00\end{array}$ & 45.53 & $40-52.07$ \\
\hline $\begin{array}{l}\text { Open-pollination + } \\
\text { Hand-pollination }\end{array}$ & 2725.70 & $\begin{array}{l}2119- \\
2940\end{array}$ & 2131.20 & $\begin{array}{l}1558- \\
2900\end{array}$ & 37.05 & $\begin{array}{l}31.25- \\
40.75\end{array}$ & 27.87 & $\begin{array}{l}23.75- \\
37.00\end{array}$ & 43.08 & $\begin{array}{l}37.90- \\
49.15\end{array}$ & 48.32 & $28.75-49.15$ \\
\hline $\begin{array}{l}\text { Without insect } \\
\text { pollination }\end{array}$ & \multicolumn{12}{|c|}{ No fruit setting } \\
\hline $\begin{array}{l}\text { Factors (mode of } \\
\text { pollination) }\end{array}$ & $\mathbf{S E}(\mathbf{m})$ & $\operatorname{SE}(d)$ & \multicolumn{2}{|c|}{ C.D. $(p=0.05)$} & $\mathrm{SE}(\mathbf{m})$ & $\mathrm{SE}(\mathrm{d})$ & \multicolumn{2}{|c|}{ C.D. $(p=0.05)$} & SE(m) & $\operatorname{SE}(d)$ & \multicolumn{2}{|c|}{ C.D. $(p=0.05)$} \\
\hline Cultivar -1076 & 0.16 & 0.23 & \multicolumn{2}{|c|}{0.47} & 0.06 & 0.09 & \multicolumn{2}{|c|}{0.18} & 0.09 & 0.12 & \multicolumn{2}{|r|}{0.25} \\
\hline Cultivar -1106 & 0.89 & 1.26 & \multicolumn{2}{|c|}{2.52} & 0.08 & 0.11 & \multicolumn{2}{|c|}{0.23} & 0.08 & 0.12 & \multicolumn{2}{|r|}{0.25} \\
\hline
\end{tabular}

Each value represents mean of 10 observations

No fruit setting ( $0 \%$ fruit set) was observed under without insect pollination treatment

Table.3 Effect of different modes of pollination on number of seed per fruit, Seed test weight $(\mathrm{g})$ and Seed germination $(\%)$ in two pumpkin cultivars

\begin{tabular}{|c|c|c|c|c|c|c|c|c|c|c|c|c|}
\hline \multirow[t]{3}{*}{ Mode of pollination } & \multicolumn{4}{|c|}{ No. of seed per fruit } & \multicolumn{4}{|c|}{ Seed test weight (g) } & \multicolumn{4}{|c|}{ Seed germination (\%) } \\
\hline & \multicolumn{2}{|c|}{ C-1076 } & \multicolumn{2}{|c|}{ C-1106 } & \multicolumn{2}{|c|}{ C-1076 } & \multicolumn{2}{|c|}{ C-1106 } & \multicolumn{2}{|c|}{ C-1076 } & \multicolumn{2}{|c|}{ C-1106 } \\
\hline & Mean & Range & Mean & Range & Mean & Range & Mean & Range & Mean & Range & Mean & Range \\
\hline Hand pollination & $\begin{array}{c}237 \\
(15.35)\end{array}$ & $126-283$ & $\begin{array}{c}219 \\
(14.54)\end{array}$ & $107-378$ & 82.75 & $\begin{array}{l}68.64- \\
89.00\end{array}$ & 59.14 & $\begin{array}{l}28.12- \\
78.25\end{array}$ & $\begin{array}{c}84.65 \\
(64.97)\end{array}$ & $82-85$ & $\begin{array}{l}75.00 \\
(64.10)\end{array}$ & $59-90$ \\
\hline Open pollination & $\begin{array}{l}290.00 \\
(17.34)\end{array}$ & $223-360$ & $\begin{array}{c}293 \\
(17.09)\end{array}$ & $232-372$ & 84.31 & $\begin{array}{c}66.89- \\
99.90\end{array}$ & 64.18 & $\begin{array}{l}37.55- \\
92.67\end{array}$ & $\begin{array}{c}90.00 \\
(72.16)\end{array}$ & $83-95$ & $\begin{array}{c}80.60 \\
(66.62)\end{array}$ & $72-96$ \\
\hline $\begin{array}{l}\text { Open-pollination }+ \\
\text { Hand-pollination }\end{array}$ & $\begin{array}{c}457 \\
(16.95)\end{array}$ & $376-526$ & $\begin{array}{c}407 \\
(20.16)\end{array}$ & $347-504$ & 88.88 & $\begin{array}{l}69.90- \\
104.00\end{array}$ & 85.91 & $\begin{array}{l}64.13- \\
109.50\end{array}$ & $\begin{array}{c}90.75 \\
(76.94)\end{array}$ & $85-97$ & $\begin{array}{c}82.75 \\
(72.37)\end{array}$ & $80-96$ \\
\hline Without insect pollination & \multicolumn{12}{|c|}{ No fruit setting } \\
\hline $\begin{array}{l}\text { Factors (mode of } \\
\text { pollination) }\end{array}$ & $\mathbf{S E}(\mathbf{m})$ & $\operatorname{SE}(d)$ & \multicolumn{2}{|c|}{ C.D. $(p=0.05)$} & $\operatorname{SE}(\mathbf{m})$ & $\mathrm{SE}(\mathrm{d})$ & \multicolumn{2}{|c|}{ C.D. $(p=0.05)$} & $\mathrm{SE}(\mathbf{m})$ & $\operatorname{SE}(d)$ & \multicolumn{2}{|c|}{ C.D. $(p=0.05)$} \\
\hline Cultivar -1076 & 0.54 & 0.76 & \multicolumn{2}{|c|}{1.55} & 0.16 & 0.23 & \multicolumn{2}{|c|}{0.47} & 1.61 & 2.27 & \multicolumn{2}{|c|}{$(4.64)$} \\
\hline Cultivar -1106 & 0.60 & 0.85 & \multicolumn{2}{|c|}{1.74} & 0.31 & 0.44 & \multicolumn{2}{|c|}{0.90} & 2.30 & 3.26 & \multicolumn{2}{|c|}{ (6.64) } \\
\hline
\end{tabular}

Each value represents mean of 10 observations

No fruit setting ( $0 \%$ fruit set) was observed under without insect pollination treatment

Figures in parentheses are angular root transformed value 
Table.1 Effect of different modes of pollination on fruit set percentage in two pumpkin cultivars

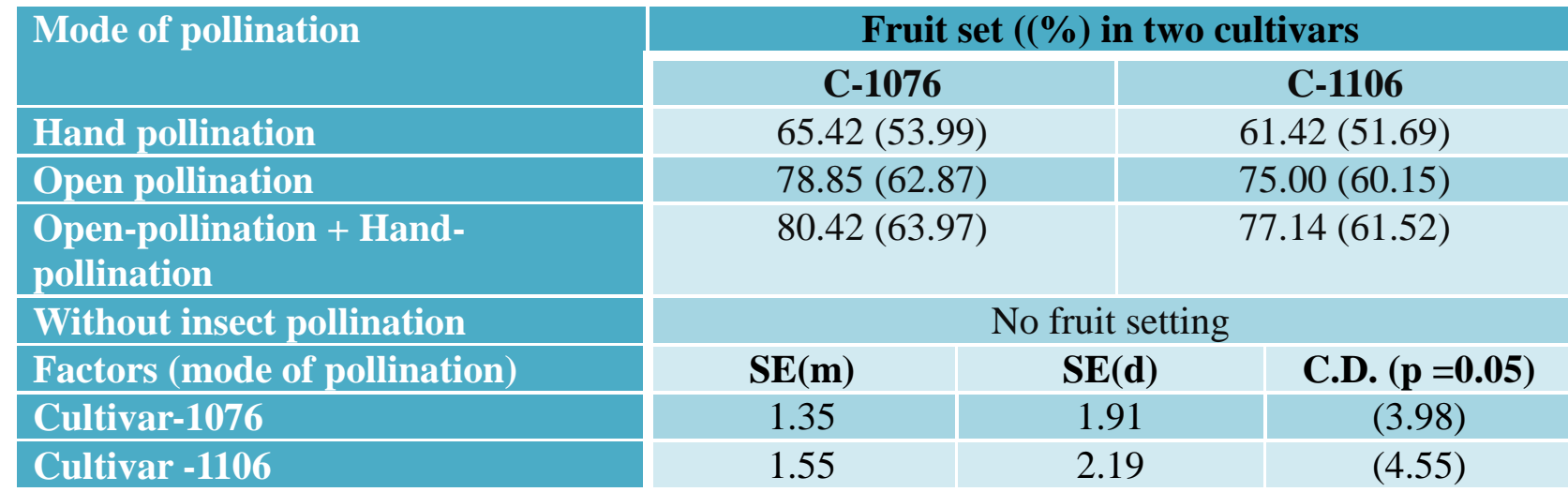

No fruit setting ( $0 \%$ fruit set) was observed under without insect pollination treatment

Each value represents mean of 10 observations

Figures in parentheses are angular root transformed value

Table.4 Effect of different modes of pollination on seed vigour I in two pumpkin cultivars

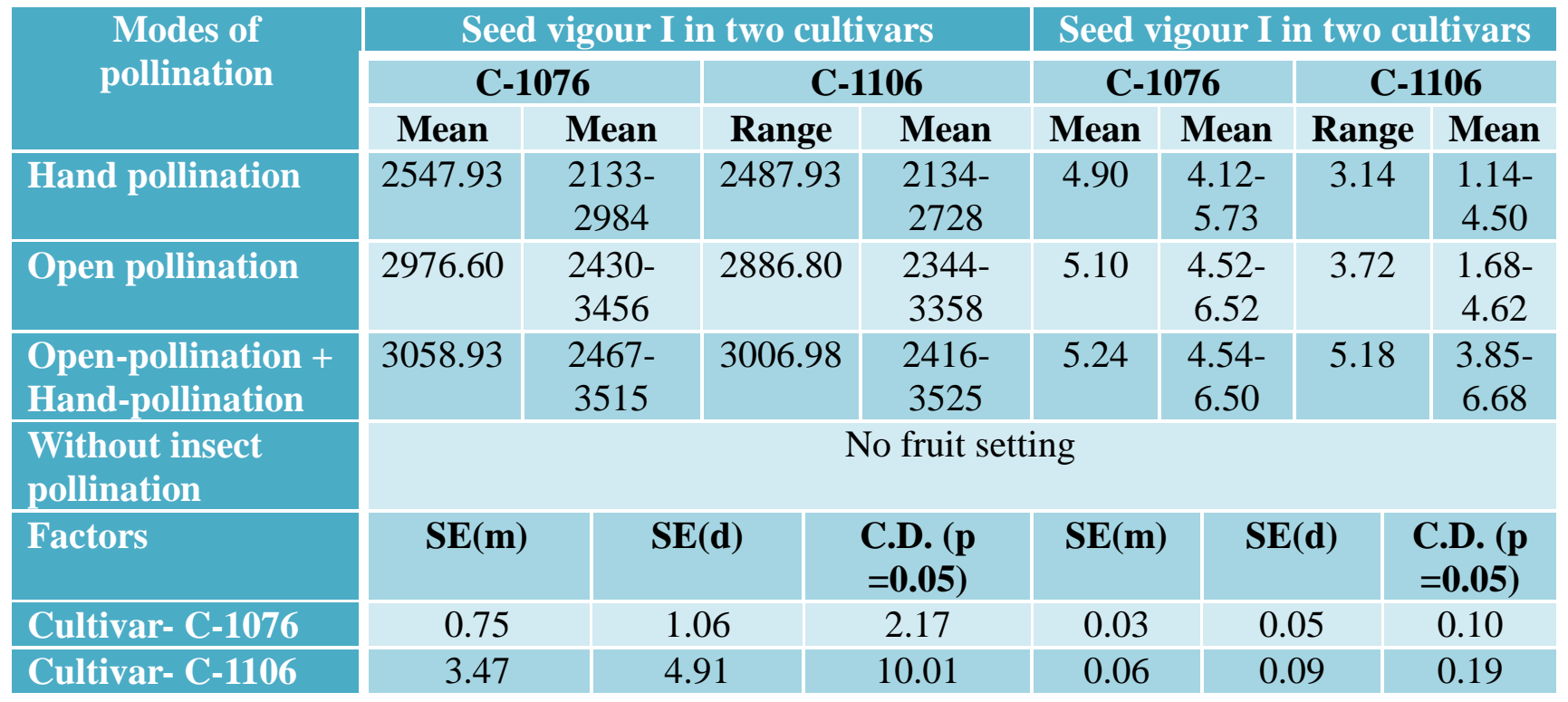

Each value represents mean of 10 observations

No fruit setting ( $0 \%$ fruit set) was observed under without insect pollination treatment

Effect of different modes of pollination on seed vigour I and seed vigour II in two pumpkin cultivars

Data in respect to the effect of different modes of pollination on seed vigour I in two pumpkin cultivars are presented in Table 4. Data show that that the average seed vigour I in two pumpkin cultivars was highest highest in open-pollination + hand-pollination (3058.93 and 3006.98, respectively) which was significantly higher than hand-pollination (2547.93 and 2487.93) and open-pollination (2976.60 and 2886.80) treatments. No fruit setting was observed in the without insect pollination treatment. Irrespective of different modes of pollination, the average seed vigour I of pumpkin fruits in two cultivars differed 
significantly among themselves. The average seed vigour II in two pumpkin cultivars, C1076 and C-1106 was the highest in openpollination + hand-pollination (5.24 and 5.18) respectively which was significantly higher from hand-pollination (4.90 and 3.14) and open-pollination (5.10 and 3.72) treatments. No fruit setting was observed in the without insect pollination treatment. Irrespective of different modes of pollination, the average seed vigour II of pumpkin fruits of two pumpkin cultivars differed significantly.

Pollination is an important role in crop production to improve crop quantity and quality and it a valuable ecosystem service, on condition that a variety of benefits including food and fiber, plant-derived medicines, ornamentals and other aesthetics, genetic diversity and overall ecosystem flexibility. For the animal-pollinated agricultural crops, bees are the most important pollinators worldwide because of their foraging behavior and floral constancy. But, only about $15 \%$ of the world's crops are pollinated by a few managed bee species, while the rest are pollinated by un-managed solitary bees and other wildlife. Our study conclude that all the fruit parameters in both the varieties was found highest in hand pollination+ open pollination followed by open pollination and hand pollination. There was no fruit set was observed in the without insect polliation treatment.

\section{Acknowledgements}

The authors are thankful to the Dr. Yogesh
Kumar, advisor and Head, Department of Entomology for providing necessary facilities. The authors also appreciate the contributions by the anonymous reviewer whose comments were useful to get the article in its final shape.

\section{References}

Cervancia, CR and Bergonia, EA. Insect pollination of cucumber (Cucumis sativus L.) in the Philippines. In: Proceedings of the Sixth International Symposium on Pollination, Tilburg, Netherlands, 1991, 278-282.

Deyto, R.C. and Cervancia, C.R. Floral biology and pollination of Ampalaya (Momordica charantia L.). Philipp. Agri. Scientist, 2009, 92(1): 8-18.

Grewal, G.S. and Sidhu, A.S. Insect pollination in Momordica charantia L. In: Abstr. Nat. Symp. Poll. Ecol. Appl. Palynol., 1979, 7-8.

Jayaramppa, K.V. Pattabhiramaiah, M. and Bhargav, H. R. Influence of beeattractant on yield parameters of ridge gourd (Luffa acutangula L.Cucurbitaceae). World Applied Sciences Journal, 2011, 15(4): 457-462.

Nogueira, C.R.H. and Calmona, R.C. Insect pollination of cucumber (Cucumis sativus var. Aodai Melhorada). Naturalia Sao Paulo., 1993, 18: 77-82.

Sarwar, G., Aslam, M., Munawar, M.S., Raja, S. and Mahmood, R. Effect of honey bee (Apis mellifera L.) pollination on fruit setting and yield of cucumber (Cucumis sativus L.). Pak. Entomol., 2008. 30(2): 185-191.

\section{How to cite this article:}

Lalita, Yogesh Kumar and Vikas. 2018. Effect of Different Modes of Pollination on Yield and Quality Paramaters of Pumpkin, Cucurbita moschata (Duch. ex Lam) Fruits. Int.J.Curr.Microbiol.App.Sci. 7(06): 3783-3789. doi: https://doi.org/10.20546/ijcmas.2018.706.443 